DOI :

\title{
Epistemological ideologies of Fyodor Dostoevsky's Notes from Underground
}

\author{
Sumaiya Tasnim
}

Brac University, Nandan Garden Shyamoli Dhaka, Bangladesh Email: sumayatasnim2@gmail.com

\section{INTRODUCTION}

Epistemology is a study of knowledge that require much attention. It is essentially considered to be a branch of philosophy which with cognitive science, history and cultural studies. In addition, it helps us study as to why our mind relates to reality and whether it is valid or invalid. Epistemologists do not necessarily study the 'conventional' knowledge instead they focus on the 'propositional' knowledge. Ideology is the belief of a set of principles which sets a man to dissect and understand a man's understanding of himself and the society. The perspective behind the relationship between epistemology and ideology fundamentally depends on how Dostoevsky looks at the society through his point of view with his understanding of the Russian society, his concerns with human psyche and his sole belief in understanding that the essence of life is beyond just 'existing'. A proposition is something that can be expressed by declarative sentence, which not necessarily a fact because it can be either true or false. The epistemology of the Russian novelist Fyodor Mikhailovich Dostoyevsky (1821-1881) can be defined through the difficult aspects of ways through which he grew up. When we talk about Dostoevsky and his childhood, initially while reading Notes from Underground(1864) we meet a nameless man living alone in St. Petersburg, Russia, in the 1860 s. We might despise him, find him contradicting or wonder how a man like him deserves to be a part of society, but interesting enough we might also feel bad for him. A sense of empathy will also exist within us because at times we realize that the underground man is within all of us. We as human beings are not free of sins at all times. Dostoevsky's idea of life and existentialism surrounds itself with embracing faith not blindly but by confronting the absurd and the experiencing the sufferings of certain emotions he faces. The book is divided into two sections called "The Underground" which was the fictional author's philosophy and "The Wet Snow" consists of the several experiences that the man feels. These experiences help the readers to understand the philosophy of both the writer and the protagonist.The idea of this very text was a criticism to Nikolai Chernyshevsky's novel What is to be done? (1863).
Dostoevsky was so critical about the idea of complexing human emotions and ideologies which are simple to decode, that instead of writing a critical review he decides to write a novel which not only criticizes Nikolai but also shows Fyodors' own ideological beliefs. Man itself is fundamentally wicked and irrational out of wickedness. A modern man will assert himself but the underground man is acting out of his ego to feel superior than everyone else.

He is absolutely incapable of being a functional human being. This confessional monologue makes us aware of a despicable side of us that affects us. However, we have to understand that this book is the underground man's book, not Dostoevsky's, even though the two coincide almost word to word. It is true that the intensity of his attacks and confessions, the lack of distance of first person narrative have given out the impression that this story of the underground man has similarities with writer's ideological positions and with the further discussion on different commentaries will also show us how that idea might as well be correct. The reason why the underground man is a very interesting character to analyze is because everything that can be said about him and against him, is something he is already very much aware of. According to him, he is in a 'paradox' since there is nothing that will amuse him since he has overheard it, anticipated it and invented it all in his mind all together. There is nothing in particular that would seem surprising to this nameless man. The way his character is built upon has put an effect on the way the book is written all together. While reading the novel we realize that the underground man cannot contain himself. He is constantly breaking decorum from time to time, interrupts himself on his own intentions, defies his readers. The idea of contradicting himself comes from the belief of his "heightened consciousness" Dwelling into the novel, the first and foremost idea we can catch is the man himself is going through an existential crisis which he eventually agrees from the beginning of text. Existentialism as we know is a philosophical movement concerned with the humanity of the individual. It centers around an individual's existence and to define himself in order to truly exist and appreciate the nature of what he has created for himself. 
We as humans must definitely go through and encounter in our daily lives experiences of coexistence or double being of self and other.In the essay "Fyodor Dostoevsky: An Analysis of Existentialism within Notes from Underground" YelizavetaRapoport mentions that, existentialism is concerned with "being" rather than just simply "existing." It is a philosophical movement that revolves around the idea that the individual has full responsibility for creating the meaning of his life (Rapoport 2).

In this paper, we will look into the ideologies that the protagonist has through his existential crisis. We will also attempt to illustrate and critically understand the thoughts brought up by the narrator which describes him as a grotesque, egoist man all in all but we will analyze why he can empathize with him all in the same time.

Before diving into the text itself it is important to see why Dostoevsky attempted to write an entire novel with response to Nikolai Chernyshevsky novel What is to be done? (1863). From the essay "Dostoevsky's Notes from Underground versus ChernyshevskyWhat Is to Be Done?" written by Jane Barstow, she mentions that the year 1864 was a time of great social and economic upheaval in Russia following emancipation of the serfs. The literary establishment is frantically at work looking for "intellectual" solutions to "political" issues (Barstow 25). The debate between Chernyshevky and Dostoevsky was initially over the idea of 'progress'. Both of the artists are extremely worried about the positive to negative shifts of the country and hence they argue that they are living at the 'opposite age' to one another. Chernyshevsky implicitly asserts that his "new men" are ushering in a positive age. He further believed that goodness will spread around history culminating in universal rationality only when positive stage has been achieved (24). Dostoevsky's underground man on the other hand as we see in the text has no belief in the goodness of mankind which shows that his character is built up on a negative ideology which is fully aware of. He denies the possibility that men can ever be fully conventionally "good". However, he does believe that man is pre-eminently a creative animal "pre destined to strive consciously towards a goal" (p. 29), but we do not see him having the faith that Chernyshevsky strongly has faith in.

The Underground man is a simple fellow who believes himself to be honest and true to himself and his only desire is the freedom of the mind and body. He thinks of himself as an intellectual who is honest about himself. So honest, that he begins his journal of life by calling himself a sick man.
The fundamental difference between the persona of the two protagonists lies in their character; the Underground Man insists in defense of his own self-destruction that man's irrational, his whimsical side is primary, that this is his "advantageous advantage," whereas Lopukhov says, perhaps in defense of his own lack of passion, that man's rational, utilitarian side is primary, that his whims are mere weaknesses that attest to man's humanity and his less than perfect present state (Barstow 25). The underground man follows in no authority although he is well aware of the laws and materialism. The petty acts and decisions of revenge and masochisms only results in exhaustion. At forty, he is an old man out of breath. He is well aware that there is nothing called a complete freedom and even if there is, the protagonist is struggling to own up to his own reality. However, he feels like he is his own hero. The reason behind this is because despite all the fundamental errors he faces, the underground man knows that he has reached to an extent in his life philosophically that most men have not dared to attempt (Dostoevsky 9). Chernyshevsky, on the contrary, believes that in a totally rational world ordered by natural laws, man will have complete freedom. However, this is freedom from want, not freedom to act.

Even while turning the pages of a music book he believes that if you turn the leaves without thinking that that act is not of a free will, however if you believe that you want to turn the pages with your right hand, you are taking a stand for yourself and hence you are the free man you want to be. (Chernyshevsky p.84). However, both the artists' belief forms a dialect of faith and socialism. Dostoevsky believes that human dignity is the most precious and impossible of human dreams, and that human happiness cannot be defined in material terms. Chernyshevsky believes that a well-paying job, a comfortable life, and freedom from economic and social evils will liberate man and make him content.

At the beginning of the novel the readers are taken aback by the idea that the protagonist calls himself a sick man but then he continues to call himself better than most men in the society through the courses of time. We therefore understand that the man is representing a confused duality all by himself.In the essay "A Psychological Critical Analysis into Dostoevsky's Notes from Underground: The Underground Man as an Outsider" written by Mohammed Al-Hiba and Dr. Ajay Tengse we see how they analyze the emotional and philosophical journey that the protagonist is suffering through. The self-pushes him on towards a normal social contact with the people around him, whereas the other hinders his approaches and stands as an obstacle between his self and the outside milieu. 
This conflicting contradiction and paradox has been the prevailing and dominant disposition of the underground man in his relations with the outside world. The distinction of the "self" and the "other" has a consistent conflict throughout the novel (et. al 81). The underground man does seem to be contradicting himself over and over again which makes him suffer but he is aware of it himself.

In order to understand the chaotic emotional impulses that the man has we need to look into the information that he provides his readers in the novel about his childhood. The underground man has had a miserably disturbed childhood and has been homeless, "If I had had a home from childhood," he tells Liza, "I shouldn't be what I am now. I often think of that. "I grew up without a home; and perhaps that's why I've turned so . . . unfeeling" (Dostoyevsky 95). Hiba and Tengse believe that in an atmosphere of warmth, security, and esteem, a child develops the necessary skills and unique alive forces of his real self: the clarity and depth of his own feelings, thoughts, wishes, interests. The special capacities or gifts he may have; the faculty to express himself, and to relate himself to others with his spontaneous feelings. All this will in time enable him to find his set of values and his aims in life. Under unfavorable conditions, on the other hand, when the people around him are prevented by their own neurotic needs from relating to him with love and respect, the child develops a feeling of being isolated and helpless in a world conceived as potentially hostile (et. al 82).

However, from a reader's point of view, I believe that any child despite his good or bad nourishment in childhood can become an existential individual once he tries to find the meaning of his existence and nature of life in the universe. However, it is true that the underground man is a part of us that we cease to not look into; we might be too afraid to find out things about ourselves. Hence we try to see what could be possibly different or 'derailed' for the underground man himself. But then again, it is essentially true that Dostoevsky's experiences had changed his thoughts and ideologies profoundly. Born in 1821, this Russian writer joined a circle of radical intellectuals in St Petersburg who were entranced by French utopian socialist theories while he was in his twenties. On 22 April 1849, Dostoyevsky was arrested and imprisoned along with the other members, and after some months of investigation they were found guilty of planning to distribute subversive propaganda and condemned to death by firing squad (BBC Insights).

The punishment was a sentence of exile and hard labor. However, Dostoevsky did not receive a death sentence but had to see many of his acquaintances and members from his team being annihilated in front of him. His harsh experiences with his life did change him profoundly but what was more interesting was his change of beliefs and thoughts.
However, he did not alter his beliefs on Russia. He firmly believed that the regulation was immoral and till the end, the author could not stand the aristocrats. Dostoevsky believed that each human beings were not in a movement where they change their beliefs from their past mistakes and become a better person for a brighter future, rather he believed that every human being stood at each moment on the edge of eternity. As a result of this revelation, Dostoyevsky became increasingly mistrustful of the progressive ideology to which he had been drawn as a young man.

While analyzing Fyodor Dostoevsky's text, the critical analysis of him through the lens of Mikhail Bakhtin is a must, because he shows the problematic notions in the novel in structure and meaning. According to Julia Kristeva, Bakhtin shows that Dostoevsky is one of the first authors to break up the unified "I" by presenting nonintegrated speaking subjects, such as the narrator in the novel; the character is not objectified, and the author offers no final solution to the contradictory ideologies that clash in the novel.Kristeva writes, "There is no third person to bring unity to the confrontation between the two; they do not culminate in a stable "I" which would be the "I" of the monologic author."(3) For this reason, both Kristeva and Bakhtin claim that there is no ideological basis in the novel anymore because the thoughts become invalid through the course of time. In Qian Zhongwen's journal, 'Problems of Bakhtin's Theory about "Polyphony"' we come to realize that Bakhtin has dealt with Dostoevsky and Dostoevskian theories for almost half a century and his "polyphony" theory is quite an influential one as it can be positively and critically looked at. The polyphonic novel which presents speaking subjects instead of defined characters, and in which the author's voice, instead of controlling the discourse from above, "descends into the polyphony of clashing ideologies and sounds with no more authority than the voices of characters with different views" (Thaden 1).

In Bakhtin's opinion, theDostoevskian "hero has his own ideological authenticity and, meanwhile, has an independent nature; he might be regarded as a creator who possessed his own complete ideology". Again, Bakhtin discovered a new feature in the novel on the basis of structure. He believed that there is a strong presence of dialogical nature in the text. He furthermore mentioned that it was this dialogical nature which made the novel 'polyphonic'. Therefore, he concludes that Dostoevsky's novel prior to "monologic fiction" is anything but that rather it should be regarded as dialogic fiction through and through. Bakhtin's conclusion in writing a successful piece of novel is if the writer wants reflect his work on reality itself, then he must make the characters more objective all the while, strengthen their subjective core in order to develop the characters accordingly. Only in this way can his purpose be achieved. But then again using this method of 'polyphony' alone Dostoevsky found new traits which made his writings more different than others. 
With the help of psychology with fiction, he strengthened his skills of attracting the readers in a way that they are taken aback with his language and objective approach to life and the characters itself. The writing of Fyodor is not conventional at all. If we notice the text itself, we will see how the novel starts with the underground man calling himself sick. Here the character himself is doing the analysis of his own character. In his notebook while talking about his principles he mentioned that, "rote, "The principle I'm now pursuing is to discover Man in the body of human beings by way of carrying out a thoroughgoing realism. ... Some people used to regard me as a psychologist, but in fact, that is wrong: I'm a realist in the highest sense; that is to say, what I want to depict is the man's whole heart of hearts" (PD 100). In his view man is both biological and social. He himself once pointed out, "man belongs to society, but, so far as his belonging is concerned, it is not totally so at all".

He believes that man is an organism that can transform. He has the right to feel things and evolve in different aspects of life. There are both positive and negative elements which shows the traits of a character and that is exactly what he wants to provide through his characters. Now Bakhtin believes that while writing a novel it is essential for the writer to leave some open ended interpretation for the readers in order to judge them. Now Dostoevsky tends to register his characters in a way where the readers know how the underground man is because he himself agrees that he is fundamentally wicked but he wants to suffer in his contradiction. Modern man will self-assert himself and fundamentally agrees that he is acting out of his ego to feel better than others. Dostoevsky does not follow the ideology that Bakhtin wants him to follow because his consciousness is from the external reality and his idea is external to himself.

However, the ideology of Bakhtin was criticized by many scholars who took a stand for Dostoevsky. Rene Welleck, in his essay "Bakhtin's View of Dostoevsky: 'Polyphony' and 'Carnivalesque"' defends Dostoevsky by mentioning that, "Bakhtin is simply wrong if he denies... the authorial voice of Dostoevsky, his personal angle of vision... Dostoevsky makes a clear judgment about the values of the points of view presented by the speakers" (6).

He believes that Dostoevsky does not lose touch on his character. He builds up his behavior for the readers in a way where this 'made up character' becomes a part of the reader's life and they can relate with him from a grotesque point of view. Welleck calls him "a man of deep commitment, profound seriousness, spirituality, and strict ethics" (7). However, it is important to understand that Bakhtin does not defy the ways of Dostoevsky nor does he accept it entirely.
Joseph Carroll offers a different opinion which does not defy Bakhtin but is not similar to what he stands for. He argues that the first part of Notes from the Underground is the psychological study and one of the most existential texts. Carroll argues that Dostoevsky has a predominant feature where he exposes the human nature of people which is incredibly involved with humiliation and passion in such a way that he does not leave space for rearranging and reflecting the characters for the readers.

In an article "Why do some Russians hate Dostoevsky?" written by Oleg Yegorkov, he mentions why Maxim Gorky one of the famous Russian writer did not prefer Dostoevsky's writing. As a socialist writer, Gorky had his reasons for not liking him since he was an orthodox monarchist. He mentions that, "Dostoevsky surely is a genius but an evil one. He felt, understood and portrayed with pleasure two sicknesses of a Russian man nurtured by our ugly history...the sadistic violence of a nihilist who's lost faith in everything and the masochism of a downtrodden creature...but this is not everything that we have, there is something more than beasts and thieves inside us! And Dostoevsky saw only them" (Yegorov 1). It is certainly safe to mention that in blood he was Russian but in thought he was European.

The concept of existentialism and how diverse it is should be discussed if we want to understand the underground man. While talking about existentialism the six main points of existentialism that Gordon E. Bigelow stands by is one of the ideal way through which we can approach existentialism by what it is. In "A Primer of Existentialism" written by Bigelow he mentions those six main points. Firstly, "existence comes before essence" which means that human beings cannot be comprehended just by their nature because existence itself is a different experience for everybody. $\mathrm{He}$ furthermore mentions that "reason is impotent" meaning existentialism finds the difference between subjective and objective truth. Another point of existentialism and one of the vital one he mentions is "alienation". An existentialist alienates himself from God, people, society and nature because we depend ourselves with nature so much that we tend to forget to check ourselves from our souls. The fourth point of existentialism is "fear and trembling" where man in general fears himself through his actions. He fears for the consequence of his effect on the society. The fifth point of existentialism is the idea to "encounter with nothingness" because when man alienates himself from God, nature and themselves they feel a sense of nothingness. Often times they try to seek comfort in sex, alcohol etc. Again according to Bigelow, sixth point of existentialism is the freedom of people includes an element in accepting that that one's choices affect one's salvation. 
Relating all the above points with the underground man gives us a hint that Dostoevsky wanted to pursue an understanding of existentialism to his readers through the lens of the character. When we say "existence comes before essence" we come to realize that the underground man firmly believes that he is different from the society. At times we can also conclude to think that perhaps, he thinks he is better than everybody. "I am to blame to first, because I'm more intelligent than everyone around me" (Dostoevsky 9). Here we can see that not only does he believe that his essence come before him existing rather he also agrees that he believes he is better than everybody.

He also finds the core difference between subjective and objective truth which brings us to the second point of existentialism which can be related to the text and the character himself. Throughout the whole novel we notice that the underground man does not necessarily have any potential friends or close relatives, which brings us to the point of Bigelow's third point of existentialism which is 'alienation'. In the book the underground man mentions, "At home, to begin with, I mainly used to read...Apart from reading I had nowhere to turn-that is, there was nothing I could then respect in my surroundings that I would be drawn into" (Dostoevsky 48). He also knew that he had no acquaintances to turn to. One of the vital points of existentialism that the underground man dwells into nothingness which brings him to the conclusion of doing everything that we mentioned before. "I longed for 'peace', I crushed me, unaccustomed to it as I was, that it even became difficult for me to breather" (Dostoevsky 126). The underground man was so accustomed to being alienated and open to having the feeling of nothingness that he could not stop wanting to be alone and find comfort into that nothingness. Despite of his potential liking of a girl, Liza, he wanted to suffer into that emotion. So, with the traits we find between the underground man and Bigelow's point of existentialism we can certainly confirm that Dostoevsky wanted to portray the true crisis his character is feeling and perhaps his readers too.

According to YelizavetaRapoport, existentialists tend to assert their understanding of the universe and surrounding by themselves. They take responsibility on their own actions without relating it to a higher being. The rants and tantrums of this man is solely independent and brutally honest. He wants to find the meaning of things through reading books and finds no meaning behind interacting with people even though he truly wants to befriend people in life. The underground man does not want to simply just 'exist'.
In an excerpt from "Being and Nothingness" Jean Paul Sartre notes that, "the human being is not only the being by whom negations are disclosed in the world; he is also the being who can take negative attitudes toward himself" (Sartre369). He further theorizes that some men in order to justify a negative part of their life, "establish their human personality as a perpetual negation". The underground man does just that through his notion of actions and justifying those with his set of beliefs. For instance, in the text, when the underground man was moved away from his position by a certain officer, he told his readers that he would have forgiven a beating, but he just could not forgive the idea that he was not being noticed. Days passed by when the man started stalking him and through many strange plans, such as writing letters to him as an anonymous stranger or planning a scene where he would put him in the officer's position just to spite him shows how much he thrives to be noticed, to be taken seriously rather than just existing to people around him. Again, these negative thoughts on how he presumes himself is also shown to us as is when he says, "I was afraid, not of six-foot tallness, nor of being beaten and chucked out of the window; I really would have had the physical courage enough; what I lacked was the moral courage" (Dostoevsky 50).

However, we cannot just pass a conclusion saying that the character here is afraid or fears of his actions because as mentioned before, the underground man can be incredibly contradicting. His 'better than thou' attitude takes a peak turn with his encounter with another female character in the novel named Liza. His encounters with her shows how absolutely incapable he was of being a fundamental human being.

The first encounter of Liza is how we notice that the idea of a female character who also happens to be a prostitute is an element for Dostoevsky to turn on the "psycho, grotesque" character hidden beneath the underground man. She becomes the object of power trip and superiority in case of intellectuality that the underground man believes he has much more than anyone else around him. Now the reason why the character of Liza is being talked about is because female characters play an essential important role in Dostoevsky's writings. As Michael Richard Murphy mentioned in his essay "The Hooker with a Heart of Gold: Dostoevsky's Complex Portrayal of Women" that we could simply pass the paradox that Dostoevsky faces while highlighting his characters just by concluding that he was a "man of his time".However, that can never be the reason for Dostoevsky, who was a nobleman and a pauper, conservative and liberal, but also a pacifist Christian and a bloodthirsty imperialist. At first, Liza seems to be the ordinary character, a prostitute by profession, uncared by her family. 
She longs for affection and idealizes love because she aims to get one someday. She treasures that one love letter from a medical student who declared his love for her. When she meets the underground man, the urge of taking care of him, being affectionate towards him shows a different side of her character than the readers could have hoped for. The underground man's attitude towards her personality and thoughts are dismissive and somewhat shallow. However, she does not share the same intellect of romanticism that the underground has. Though Dostoevsky believed that women should remain in their established domain as wives and mothers, he only advocated this conservative path because believed that women formed the backbone of a strong Russian society (Murphy 2). Both the underground man and Liza are lost souls who want to seek Christian redemption and both are denied. Somehow, strange enough the underground man overshadows Liza's character making it his own or a partial representation of beliefs. Even though Liza had to offer peace and love, the underground man throws it off with lies and sexual abuse, which shows how the female character was just a tool to show one of the most grotesque scenes in the entire novel. Dostoevsky silences the marginalized female characters which only idealizes his central male characters. Janine Langan noticed this duality that mixes Christian symbolism and self-mutilation:

The human propensity for more or less angelic pornography haunts Dostoevsky's novels. He has a unique, lurid talent for arousing in his reader the peculiar thrill linked to sado-masochist fantasies... (65)

When we think about it, be it Crime and Punishment, Poor Folk or Notes from the Underground we notice that there was no novel or a piece of writing where, Dostoevsky never represented a strong female character if not a female protagonist. In a Bakhtinian analysis, these characters are monologist and they are given very few spaces to perform or have a legitimate stand in order to address the audience with their own pace of time. All the women suffer from being dominated by the male protagonist. So from one point of view we can say that Liza is actually not a character, rather a 'tool' through which we can dwell into the underground man's character more deeply. Therefore, we can see the idea of creating a character as a tool rather than an important highlight to the novel is one of the theoretical devices in the novel.

The reason why we are looking into the character of Liza is directly linked with the Christian ideologies that sparks in the novel because of the beliefs of the author. However, the questions remain as to how Liza "reawakens" the Christian martyr in the underground man, if she was never violent rather she took it in.
Robert Jacksan in his journal "Aristotelian Movement and Design in Part Two of Notes from the Underground." Dostoevsky: New Perspectives.", mentions in a very interesting manner that, the second time the underground man decides to meet Liza was pure of an unexpected turn of events from this 'pretentious spur of the moment'. However, when they do meet, the underground man murders Liza both spiritually and morally. This can be clearly noticed when he mentions his true intentions towards her by remarking 'She turned white as a handkerchief, wanted to say something, her lips working painfully, collapsed in the chair as if felled by an ax"' (Jackson 73). Hence, we again see that Liza was indeed a tool for her 'spiritual awakening' even though the underground man did not seek the Christian path for repenting but Dostoevsky made Liza the innocent tool who was just enough to trigger that notion in him.

At first when we try to break down the psyche of the underground man we realize that this man is in a paradox of his realization which comes from his self-accusation. Joseph Frank while analyzing the novel and the character himself agrees that, the underground man realizes the guilt he feels, his belief towards moral notions, abolishing himself from the society and the laws yet abiding by it all at the same time (Frank 12). The word "real", "reality" and notions of real life tends to bring in ironic effects in the novel as well. For instance, in the beginning the underground man used the one of 'real life' and 'reality' as a sense of explaining his life which includes only free will and not pacing with the society but as we gradually go into the novel we realize that the protagonist forms a sort of ironic idea of the term 'reality' as he mentions, "We have lost touch so much that occasionally we cannot help feeling a sort of disgust with 'real life,' and that is why we' are so angry when people remind us of it. Why, we have gone so far that we look upon ' real life' almost as a sort of burden, and weare all agreed that ' life' as we find it in books is much better . . .. So that as a matter of fact, I [who reject books] seem to be much more really alive than you... [who] even find it hard to be men ... of real flesh and blood. " (Dostoevsky 32).

But we know where the underground man comes from. We understand his psyche, his disturbed thoughts and beliefs from not wanting to be in a social jail but having to fight to stay in one, not wanting to make friends but wanting to be a part of every conversation given the chance. We know all that and we can relate to everything. The reason behind this is purely because we all are the underground man. The idea of finding the protagonist so grotesque and disturbing from the beginning of the novel can be because of the pure realization that Dostoevsky hit his readers with the harsh truth from the beginning of the novel. 
The readers knew exactly what they were going into because Dostoevsky's intention was not to create a 'ground breaking', soul trembling climax but to shake his readers with the truth that they themselves might feel uncomfortable to find and he successfully did just that. In a personal correspondence, Fyodor Dostoevsky said that, "To study the meaning of man and of life - I am making significant progress here. I have faith in myself. Man is a mystery: if you spend your entire life trying to puzzle it out, then do not say that you have wasted your time. I occupy myself with this mystery, because I want to be a man"

Dostoevsky was always in search of the truth, but not necessarily the scientific truth rather the truth to find himself. One of the most important existential messages that the author had to give was to always be 'authentic to yourself'. The idea of freedom of full scope individuality is the ideal way to find the truth. In the grand scheme of things, the author believes that nothing can be more important than finding your true self. He believes that following an abstract ideology fulfills nothing unless you realize the meaning of your own life. What Fyodor Dostoevsky did was put his ideological beliefs in the underground man making a made up character more alive and aware than most people that we surround ourselves with. The underground man had similar beliefs and was absolutely sure of what he believed in, even though at times he did not follow it because of belonging in a society, having a job that we did not want to be in, but had to carry on nevertheless.Relativists believe morality is arbitrary. Through this Underground Man, Dostoevsky shows that there is a moral necessity to live properly. You have free will, you have choice, but you cannot just sit in isolation and be useless and resentful or else you will regret everything around you and suffer for it.

However, when an author brings about a question of a problem, that must have a solution. The underground man is a self-proclaimed intelligent man who know he is up to no good and is aware of his life and meaninglessness of being alive. The question comes as to why he does not commit self-harm or become suicidal? The reason is given in the novel itself. The protagonist is well aware of facts but he believes that there might be light at the end of the tunnel. The novel criticizes the ideology of the 'social standards that are acquired'. He is conscious of the external reality. When the socially inherited ideology is corrupted, we become corrupted. The underground man is brutally authentic and had it not been the underground itself, the man could have never been so original and self-righteous, because being within a social bubble creates certain '-isms' which constricts us from having thoughts or finding the fundamental truth about oneself. Now blind submission to rationality makes a man ignorant because what you do without any purpose whatsoever is the authentic ideology itself. The church once known as freedom, now acts as a 'righteous path' but through dominations and limitations by promising you security through fear. Fear of system, fear of God, fear of our surroundings.
Now freedom is not easily possible and really difficult to attain. Without anguishing pain, nothing is possible. According to Dostoevsky, we need suffering, torment, contradiction, anguish in order to experience freedom.

The underground man wants to find a solution for his behavior and characteristics which brings him discomfort and hence he wants to become normal. He falls into this paroxysm where he feels a sense of grudge and jealousy towards 'normal' beings. "I envy such a man with all the forces of my embittered heart," says the underground man. Although, the underground man conceives this normal man as stupid, it does not seem to him way too pricey to trade for his freedom andemancipation, so to speak. He wishes to be normal even if it means stupidly normal, "He is stupid. I am notdisputing that. But perhaps the normal man should be stupid," (Dostoyevsky 13), the underground man says. According to the article written by CRB on "DOSTOEVSKY AND REASONING CHRISTIANITY", they mention that "Notes from Underground is a no-nonsense polemic against British utilitarianism as espoused by Jeremy Bentham and John Stuart Mill. It is a "rejection of reason" only if reason is understood as the sole wellspring of truth. As a Russian Orthodox Christian, Dostoevsky knew that faith must guide and direct the mind; unaided reason contorts reality. The twisted figure of the "underground man" asserts his will, but in his poignant dramatic monologue, he defends his freedom as a human being against a truncated view of reason and truth."

Dostoevsky talked against the system, often hated by people from his own land who believed that he was Russian by birth but a European by nature. Again, Bakhtin's response to the novel makes complete sense when we try to find the solution to this anguishing paradox of existentialism, there is none. The underground man is aware of his evil memories but as he writes it through the lens of literature it is not repentance that we see rather it is a form of self-punishment. He believes that every novel needs a hero, but he is the anti-hero of his own story. He is aware that readers would rather read about fantasies and stories that they would enjoy and leave a lasting memory but the underground man is aware that his painfully truthful novella will bring in more emotions than any other novel because he faced life more acutely and had no shame in confronting it.

Fyodor Dostoevsky like every other authors had this own ideologies, but what is different about the underground man than all the other novels are the fact that the setting, the characters surrounding the protagonists were just tools to centralize on the main character. There was a message that the author wanted to portray not a mere story. The contradicting, paradoxical tendencies of the underground man put the readers into a never ending thought loop but the solution to these problems of the underground man is open ended. 
It is up to us to decide what can be learned from an anguishing man who does not necessarily repent rather expresses his thoughts and is awfully confident about his ideologies. The novel makes us question and realize elements of existentialism, social constructionism and author's principal beliefs all at the same time. Dostoevsky crafted his novel in a certain angle where his readers would not only relate to the underground man, rather question the man and themselves simultaneously.

\section{REFERENCES}

1. "A Point of View: The Writer Who Foresaw the Rise of the Totalitarian State." BBC News, 23 Nov. 2014, www.bbc.com/news/magazine-30129713. Accessed 9 Aug. 2019.

2. Barstow, J. Dostoevsky's Notes from Underground versus Chernyshevsky'sWhat Is to Be Done?.Jstor, 5(1), 24-33. Retrieved from http://www.jstor.org/stable/25111196

3. Carroll, J. 1974 Break out from the Crystal Palace: the anarchophysiological critique Sitrner, Nietzsche, Dostoevsky, Routledge and Kegan Paul, London

4. "Dostoevsky and Reasoning Christianity." Claremont.Org, 2019 ,

www.claremont.org/crb/article/dostoevsky-and-reasoning-christia nity/. Accessed 9 Aug. 2019.

5. E. Bigelow, Gordon. "A Primer of Existentialism." Jstor, www.jstor.org/stable/373002.

6. Fyodor Dostoevsky, Notes from Underground, tr. Ralph E. Matlaw (New York: Dutton, 1960), p. 18. Subsequent references to this edition will appear in the text

7. Hiba, Mohammad Al, and Dr. Ajay Tengse. "A Psychological Critical Analysis Into Dostoevsky's Notes From Underground: The Underground Man As An Outsider". Iosrjournals.Org, 2019, http://www.iosrjournals.org/iosr-jhss/papers/Vol20-issue10/Versi on-3/L0201038185.pdf.

8. Jackson, Robert Louis. "Aristotelian Movement and Design in Part Two of Notes from the Underground." Dostoevsky: New Perspectives. Ed. Robert L. Jackson. Englewood Cliffs, N.J: Prentice-Hall, 1984. 72-77.
9. M. M. Bakhtin, Problems of Dostoevsky's Poetics, tr. Bai Chunren and GuYaling (Beijing, 1988); hereafter cited in text as PD .

10. M. M. Bakhtin, The Aesthetics of Verbal Creation (Moscow, 1979), p. 318; hereafter cited in text as AV

11. Murphy, Michael. The Hooker with a Heart of Gold: Dostoevsky's Complex Portrayal of Women.2009.

12. N. G. Chernyshevsky, What is to be Done? tr. E. H. Carr (New York: Random House, 1961),

p. 175. Subsequent

references to this edition will appear in the text.

13. Oleg Yegorov. "Why Do Some Russians Hate Dostoevsky?" Rbth.Com, 15 Aug. 2018, www.rbth.com/arts/328963-russia-dostoevsky-hate. Accessed 30 July 2019.

14. Personal correspondence (1839), as quoted in Dostoevsky: His Life and Work (1971) by Konstantin Mochulski, as translated by Michael A. Minihan, p. 17

15. Rene Wellek, "Bakhtin's View of Dostoevsky: 'Polyphony' and 'Carnivalesque', Dostoevsky Studies 1 (1980), p. 32-33.

16. Smith, Nicole. "Concluding Thoughts: The End of Notes from the Underground." ARTICLEMYRIAD, Www.articlemyriad.com/concluding-thoughts-notes-underground.

17. Stanford Encyclopedia of Philosophy, "Relativism, roughly put, is the view that truth and falsity, right and wrong, standards of reasoning, and procedures of justification are products of differing conventions and frameworks of assessment and that their authority is confined to the context giving rise to them."

18. Thaden, Barbara. "Dostoevsky Studies: Bakhtin, Dostoevsky, and the Status of the 'I."' Utoronto.Ca, sites.utoronto.ca/tsq/DS/08/199.shtml.

19. Zhongwen, Qian. "Problems of Bakhtin's Theory about "Polyphony."' Jstor, www.jstor.org/stable/20057455. 